\title{
The Impact of Organisational Factors on Organizational Commitment at the Arab Bank in Jordan
}

\author{
Abdullah Abbas Al-khrabsheh ${ }^{1}$, Ahmed Kh. Muttar ${ }^{2}$, Omar Rabeea Mahdi' ${ }^{2}$, Islam A. Nassar ${ }^{2}$ \& Sakher A.I \\ AL-Bazaiah $^{1}$ \\ ${ }^{1}$ Prince Al-Hussein Bin Abdullah II academy of Civil Protection, Al-Balqa Applied University, Jordan \\ ${ }^{2}$ Applied Science University, College of Administrative Sciences, Kingdom of Bahrain \\ Correspondence: Abdullah Abbas Al-khrabsheh. E-mail: abdbbs@gmail.com
}

Received: March 4, 2018 Accepted: March 26, 2018 Online Published: June 22, 2018

doi:10.5539/ass.v14n7p26

URL: https://doi.org/10.5539/ass.v14n7p26

\begin{abstract}
This study aims to examine the impact of emotional intelligence and job satisfaction on organisational commitment. Data are collected from sample of 102 employees working in the Arab Bank which is a one of the most important bank in Jordan. The multiple regression analysis is used to analyze the proposed hypotheses. The results indicate that emotional intelligence and job satisfaction have strong and positive impacts on organizational commitment. Lastly, the implications of this study provided support for the scholars of organizational factors, particularly in banking sector.
\end{abstract}

Keywords: emotional intelligence, job satisfaction, organisational commitment

\section{Introduction}

Nowadays, emotional intelligence is recognized as a one of the solutions for increasing employees' job satisfaction and organizational commitment (Aghdasi, Kiamanesh, \& Ebrahim, 2011). Besides, organizations have to improve the commitment of their employees with high satisfaction and efficiency to the organization to ensure that they stay in the organization and to increase their efficiency. In addition, it is very important that employees are satisfied with their work so that they can be committed to their organizations (Aksoy, Şengül, \& Yilmaz, 2018). In other words, employees with high commitment to their organizations expected to perform better than those with lower levels of commitment to their organizations (Aghdasi et al., 2011). Practically, organisations in general and banking sector in particular, cannot continue ignoring staff high organisational commitment, as they considered a key factor in their existence (Kumari \& Priya, 2015). In this regard, Hafiz (2017) argues that organisational commitment a basic issue for the owners of companies and management such as banks. In addition, he concludes that the dimensions of organisational commitment, both independently and jointly, influence the employees' performance in banks. It means that employees are willing to devote to and stay in banks until they have accomplished the objectives of their jobs because they have the same goals and values inside the organisation (Hafiz, 2017). However, emotional intelligence is considered a reasonable power of predictability toward the organisational commitment (Shafiq \& Rana, 2016). Moreover, emotional intelligence, and the job satisfaction of employees are the significant variables for the success of institutions in a competitive environment (Orhan \& Dincer, 2012). Therefore, the current study aims to investigate the impacts of emotional intelligence and job satisfaction on organisational commitment among the employees in the Arab Bank in Jordan.

\section{Literature Review}

\subsection{Emotional Intelligence}

Mayer and Salovey (1999) define emotional intelligence as a crucial factor for societal intelligence, whereby one can observe their own and others' feelings and emotions and establish the best practices for better implications as a consequence. Since the early 1990s, many experts have shifted the focus of their research to human psychological and cognitive capacity enhancement. New ideas have been put forward as a result of the association between intelligence and emotions. Studies indicate that individuals with better cognitive abilities, those who can pinpoint their emotions and are able to regulate them whenever required, have a better insight into other people's emotions and conduct, which in consequence could bring about better relations toward positive 
results in their daily lives. Additionally, a crucial positive relationship has been discovered between emotional intelligence and social effectiveness. The studies state that as the levels of emotional intelligence increase, the social associations get better, especially in jobs where human contact is greatly involved. Ever since, emotional intelligence has been correlated with many subjects such as social conduct, mental wellbeing, academic accomplishments, dealing with stress, organisational functioning and job dedication. Research implies that acknowledging $\mathrm{E}$ emotional intelligence $\mathrm{I}$ is an effective way of regulating job performance in the place of work, which helps employees to adopt the best organisational practices on an actual basis.

The current study employs Mayer and Salovey's (1997) four-branch emotional intelligence ability model; as per this model, emotional intelligence is described as "ability to identify emotions, to read and generate emotions in order to assist thought, to be aware of emotions and emotional experience, and to reflectively control emotions in order to promote intellectual and emotional growth" (p. 4).

\subsection{Job Satisfaction}

Sarwar and Aburge (2013) claim that there are many people who go to work daily for several years and where they dedicate long hours doing work whether they like it or not. They do it only to earn a living. This is despite job satisfaction being a matter of concern for the shareholders and the owners of the corporation for the last 20 years. Moreover, job satisfaction has been an interesting construct for many researchers in understanding employee attitudes and behaviours (Siron, Muttar, \& Ahmad, 2015). The research areas such as psychology and business came into existence because management teams and the senior executives felt a rising concern regarding job satisfaction and its importance in enhancing the overall performance of the organisation.

Fundamentally, job satisfaction concerns how satisfied an individual is with his/her work. Nonetheless, research has proven that it is not just about the nature of work and what it involves. Besides that, it also depends on the prospect of the job that the employees might hold from the beginning, and which might be different for all the employees. These expectations arise as a combination of different fundamental factors such as the beliefs, needs, values and aspirations that every individual has. Thus, studies have proposed that every employee should evaluate his/her job satisfaction considering these factors. As a result, people would have a better job satisfaction level if there were a balance between the expectations from the job and these personal factors.

Moreover, studies have broadened their scope and obtained promising outcomes as they discovered that several other factors could cause changes in the job satisfaction level of individuals. Some of these factors are work environment, job security, appraisals, teamwork, structure of the organisation, remuneration, perks and efficiency in the workplace. As the studies continue, there are other factors to be considered such as leadership and social associations, the demanding nature of work, employee participation and empowerment. The experts agree on the common outcome of these studies, which is that the higher the level of job satisfaction, the more optimistic the attitude that is achieved in the workplace, which in turn enhances the overall organisational performance over a long time.

Job satisfaction in this study is described as "an overall amount of the degree of the employee's contentment and satisfaction with the work" (Hackman \& Oldham, 1974, p. 10). For the purpose of the current study, job satisfaction is also defined as the extent to which one feels positively or negatively about the intrinsic and extrinsic aspects of one's job (Bhuian \& Mengue, 2002; Siron, Muttar, Ahmad, \& Tarsipan, 2016).

\subsection{Organisational Commitment}

Organisational commitment is a condition in which an employee identifies himself/herself with a particular organisation and its objectives, and wants to remain its participant (Khan \& Jan, 2015). It is commonly believed that committed employees will also work harder to achieve organisational objectives (Meyer \& Allen, 2004). Moreover, organisational commitment refers to the level to which an employee is faithful to his/her organisation (Al-Aameri, 2000; Khan \& Jan, 2015; Tayyab \& Riaz, 2004). Therefore, in the current study, organisational commitment is operationalised as the employee attitude toward his/her organisation (Peng et al., 2016) in terms of normative, affective and continuance commitment. The affective commitment is defined as the feeling of belonging to the company and the degree of loyalty to the firm (Meyer \& Allen, 1984, p. 375). The normative commitment represents the employee's feelings of obligation to remain with the organisation (Allen \& Meyer, 1996, p. 253). The continuance commitment is the level of commitment that individuals feel towards the employing company when they weigh the penalty of resigning from the organisation.

\subsection{Hypotheses Development}

The theoretical framework proposed in this study illustrated in Figure 1 goes further to explain the relationship between the organizational factors (emotional intelligence and job satisfaction), and organizational commitment. 


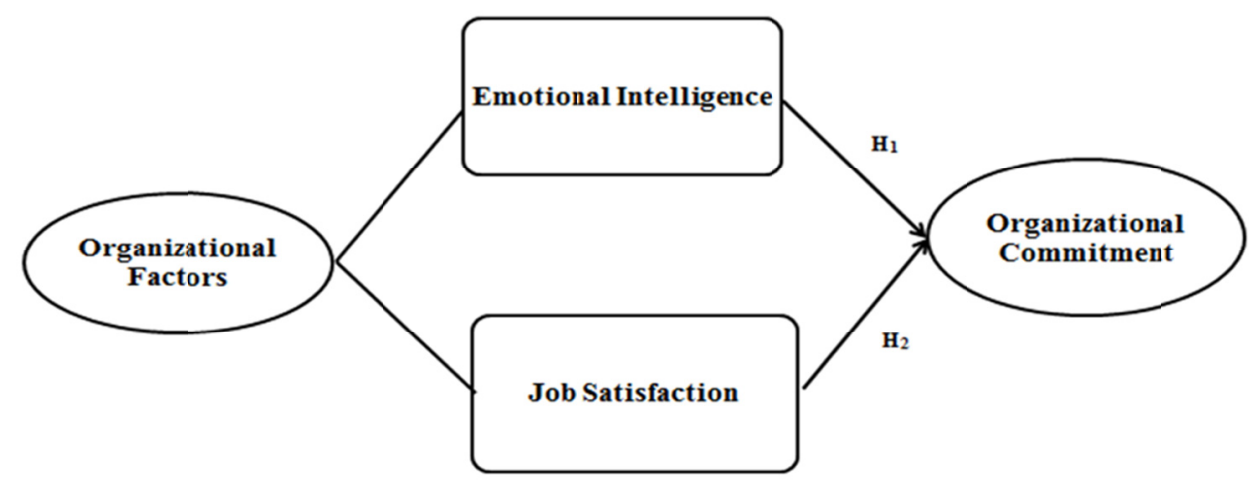

Figure 1. Theoretical framework

Based on the theoretical framework, the following hypotheses are proposed to examine the relationship among emotional intelligence, job satisfaction and organisational commitment.

Sinha and Jain (2004) investigate the relationship between organisational commitment and emotional intelligence from an Indian perspective. The research states that recognising the emotional intelligence of the employees in an organisational context may be one of the most significant predictors of organisational commitment. Moreover, there are several other researchers globally trying to incorporate several variables in their studies about the relationship between emotional intelligence, job satisfaction and organisational commitment depending on their social nature; all of them agree on the profound correlation between these factors and organisational performance. Iordanoglou (2007) suggests that emotional intelligence has a positive effect on leadership efficiency and it is greatly linked with job satisfaction and organisational commitment. He discovered this by carrying out research on the relationship between leadership, emotional intelligence, job satisfaction and organisational commitment conducted on primary teachers based in Greece. The study was conducted with the belief that teachers are the coordinators in class. Additionally, the same study implies that cognitive capabilities and professional competency are to be considered alongside the emotional competencies in the selected group. Researchers argue that emotional intelligence is a key factor in increasing organisational commitment (Aghdasi, Kiamanesh, \& Ebrahim, 2011). In this regard, the study of Alavi, Mojtahedzadeh, Amin and Savoji (2013) investigates the relationship between emotional intelligence and organisational commitment; their results show that emotional intelligence is positively related to the organisational commitment. Therefore, it is hypothesised that:

\section{$H_{1}$ : Emotional intelligence is significantly related to organisational commitment.}

The relationship between job satisfaction and organisational commitment was examined by Sosyal and Dergisi (2018). The data were collected from 492 employees working in four and five-star hotel businesses in the provinces in the Southeastern Anatolia region of Turkey The results reveal that affective commitment and normative commitment have a positive relationship with employee satisfaction and a negative relationship with continuance commitment. In the same context, Lizote, Verdinelli and Nascimento (2017) employ the theoretical model of Meyer and Allen (1991) to address organisational commitment. Their results show that affective commitment is significantly related to job satisfaction, and a significant relationship between normative commitment and job satisfaction were also determined. Therefore, the current study hypothesises that:

\section{$\mathrm{H}_{2}$ : Job satisfaction is significantly related to organisational commitment.}

\section{Method}

For the purpose of statistical analysis, the data collected from the sample of 102 employees working at the Arab bank were analyzed using the SPSS software package, version 23.0.

Initially, the data were gathered using the questionnaire included two sections. The first section is demographic information of the respondents and second section is about the organisational factors including emotional intelligence and job satisfaction, and organisational commitment. To attain the objectives of the current study, a list of items that measured the study variables was developed. In addition, these measurements have been employed and validated in earlier studies and were adapted to measure job satisfaction, emotional intelligence and organisational commitment among the employees in Arab bank in Jordan. The five-point Likert scale 
ranging from strongly disagree (1) to strongly agree (5) has been used in current study.

Emotional intelligence construct was measured in terms of four dimensions; perception and assessment of emotions, facilitating thoughts with emotions, understanding emotions, and regulation and handling of emotions. Emotional intelligence notion was adopted from Groves et al. (2008) by including 24 items, 6 items for each one. Subsequently, an emotional intelligence measurement device was validated by Turnipseed and Vandewaa (2012). The job satisfaction construct was obtained from the scale first created by Hackman and Oldham (1974) with five dimensions measured employing 14 items, 2 items for pay, 2 items for job security, 3 items for social, 3 items for supervisor, and 4 items for growth satisfaction; this was also validated by Fried and Ferris (1987). The current study adopted the measurement of organisational commitment from Meyer, Allen and Smith (1993), which was also validated by Lizote, Verdinelli and Nascimento (2017). The measurement of these authors contains the total of 18 items for the three dimensions; affective, normative, and continuance commitment, with 6 items under each dimension.

\section{Results}

The respondents are 102 employees working at the Arab bank. Among the employees, 69 were male and 33 female. The distribution of the different age groups among the responding is as follows: 19 were between $18-25$ years and 33 between 26 - 35 years, 47 were between 36 - 45 years, and finally, 3 were 46 and above. In terms of the education level: 8 with MS and Ph.D., 10 with Masters, 52 holding Bachler degree, 20 with Diploma, and finally, 10 of employees were with secondary school certificate.

Descriptive statistics are computed for all data prior to the stage of conducting the detailed statistical analyses. The Mean and standard deviation are computed. The emotional intelligence mean is $3.85(\mathrm{SD}=0.554)$; the job satisfaction mean is $3.56(\mathrm{SD}=0.509)$, and the organisational commitment mean is $3.72(\mathrm{SD}=0.575)$. The Pearson product moment coefficient correlation is used to explain the relationship between the study variables. The results of the descriptive statistics, coefficient correlation, and Cronbach's alpha for each measure are presented in Table 2.

Table 1. Descriptive Statistics, Coefficient Correlation, and Cronbach's Alpha

\begin{tabular}{cccccc}
\hline Varibals & Mean & Std. Divation & 1 & 2 & 3 \\
\hline Emotional Intelligence & 3.85 & .554 & -0.88 & & \\
Job Satisfaction & 3.56 & .509 & $.56^{* *}$ & -0.74 & \\
Organisational Commitment & 3.72 & .575 & $.71^{* *}$ & $.60^{* *}$ & -0.75 \\
\hline
\end{tabular}

**Correlation is significant at the 0.01 level (2-tailed).

Table 3 demonstrates the results for regression analysis. Hypothesis $H_{1}$ states that there is a significant relationship between emotional intelligence and organisational commitment. Based on the Beta coefficient in Table 3, the results show that the relationship between emotional intelligence and organisational commitment is significantly indicative of $\beta=.17$ and it indicates that the $p$-value $=.04<.05$. Therefore, hypothesis $\mathrm{H}_{1}$ is accepted. Furthermore, Hypothesis $\mathrm{H}_{2}$ states that there is a significant relationship between job satisfaction and organisational commitment. The results in table 3 indicate significant relationship between job satisfaction on organisational commitment as $\beta=.23$ at the $p$-value $=.02<.05$. Thus, hypothesis $\mathrm{H}_{2}$ is supported.

Table 2. The Results of Regression Analysis

\begin{tabular}{cccccc}
\hline Varibals & $\begin{array}{c}\text { Standardized Beta } \\
\text { coefficient }\end{array}$ & Std. Error & $\begin{array}{c}\text { Unstandardized } \\
\text { Beta coefficient }\end{array}$ & T. value & Sig. \\
\hline Emotional Intelligence & .17 & .080 & .17 & 2.081 & .04 \\
Job Satisfaction & .23 & .086 & .20 & 2.67 & .02 \\
\hline
\end{tabular}

Dependent variable: organizational commitment

\section{Discussion and Conclusion}

The result from the analysis of first hypothesis reveals that there is high significant relationship between emotional intelligence and organizational commitment. This means, it is possible to increase the organizational 
commitment of the employees through their emotional intelligence. The results of the current study strengthened with the result of the Kumari and Priya (2015), who tested the same relationship between emotional intelligence and organisational commitment among employees in public sector banks in Dehradun (U.P.) India. According to the findings, the employees who have higher emotional intelligence are more committed to their organizations.

In the current study, the relationship between job satisfaction and organizational commitment was also tested. It was assumed that a significate relationship between job satisfaction and organizational commitment. It means that high level of job satisfaction of the employees in Arab Bank create a high level of organizational commitment. It was seen that the results obtained were similar to some previous studies in the literature such as, Lizote et al. (2017), and Aksoy et al. (2018), who found that high levels of employees' job satisfaction increase their organizational commitment. In conclusion, we can say that the employees who have high level of emotional intelligence and job satisfaction have high organizational commitment to their organization. To the best of researchers' knowledge, the implications of this study provided support for the scholars of organizational factors, particularly in banking sector. Moreover, the knowledge about emotional intelligence and its impacts gives new inspirations to human resources management concerning the actions to perform in order to enhance the performance and commitment of their employees.

\section{References}

Aghdasi, S., Kiamanesh, A. R., \& Ebrahim, A. N. (2011). Emotional intelligence and organizational commitment: Testing the mediatory role of occupational stress and job satisfaction. In Procedia - Social and Behavioral Sciences, 29, 1965-1976. https://doi.org/10.1016/j.sbspro.2011.11.447

Aksoy, C., Şengül, H. I., \& Yilmaz, Y. (2018). Examination of the relationship between job satisfaction levels and organizational commitments of tourism sector employees: A research in the south eastern Anatolia region of Turkey. Elektronik Sosyal Bilimler Dergisi, 17(65), 356-365. https://doi.org/10.17755/esosder.343032

Alavi, S. Z., Mojtahedzadeh, H., Amin, F., \& Savoji, A. P. (2013). Relationship between emotional intelligence and organizational commitment in Iran's Ramin thermal power plant. In Procedia-Social and Behavioral Sciences, 84, 815-819. https://doi.org/10.1016/j.sbspro.2013.06.653

Allen, N. J., \& Meyer, J. P. (1990). The measurement and antecedents of affective, continuance and normative commitment to the organization. Journal of Occupational Psychology, 63, 1-18. https://doi.org/10.1111/j.2044-8325.1990.tb00506.x

Allen, N. J. \& Meyer, J. P. (1996). Affective, continuance, and normative commitment organizationally relevant outcomes. Psychological Studies, 49(2), 81-96.

Beck, J. H. (2013), Emotional Intelligence in Everyday Life. U. K.: Psychology Press.

Bhuian, S. N., \& Mengue, B. (2002). An extension and evaluation of job characteristics, organizational commitment and job satisfaction in an expatriate, guest worker, sales setting. Journal of Personal Selling \& Sales Management, 22(1), 1-11.

Clutterbuck, D., \& Megginson, D. (1999). Mentoring executives and directors. Oxford: Butterworth-Heinemann.

Fried, Y., \& Ferris, G. R. (1987). The validity of the job characteristics model: A review and meta-analysis. Personnel Psychology, 40, 287-322. https://doi.org/10.1111/j.1744-6570.1987.tb00605.x

Hackman, J. R., \& Oldham, G. R. (1974). The job diagnostic survey: An instrument for the diagnosis of jobs and the evaluation of job redesign projects. Department of Administrative Sciences: Yale University.

Hafiz, A. (2017). Relationship between organizational commitment and employee's performance evidence from banking sector of Lahore. Arabian Journal of Business and Management Review, 7(2), 1-7.

Huy, Q. H. (1999). Emotional capability, emotional intelligence, and radical change. Academy of Management Review, 24, 325-345. https://doi.org/10.5465/amr.1999.1893939

Iordanoglou, D. (2007). The teacher as leader: The relationship between emotional intelligence leadership effectiveness, commitment and satisfaction. Journal of Leadership Studies, 1(3), 57-66. https://doi.org/10.1002/jls.20025

Kumari, P., \& Priya, B. (2015). The role of emotional intelligence in organizational commitment: A study of banking sector. Global Journal for Research Analysis, 4(11), 59-62.

Lizote, S. A., Verdinelli, M. A., \& do Nascimento, S. (2017). Organizational commitment and job satisfaction: a study with municipal civil servants. Brazilian Journal of Public Administration, 51(6), 947-967. 
Masa'deh, R., Maqableh, M., \& Karajeh, H. (2014). A theoretical perspective on the relationship between leadership development, knowledge management capability, and firm performance. Asian Social Science, 10(6), 128-137. https://doi.org/10.5539/ass.v10n6p128

Mayar, J. D., \& Salovey, P. (1995). Emotional intelligence and the construction and regulation of feeling. Applied and Preventive Psychology, (4), 197-208. https://doi.org/10.1016/S0962-1849(05)80058-7

Mayer, J. D., \& Salovey, P. (1997). What is emotional intelligence? In P. Salovey \& D. Sluyter (Eds.), Emotional development and emotional intelligence: Implications for educators (pp. 3-31). New York, NY: Basic Books.

Mayer, J. D., \& Ciarrochi, J. (2006). Clarifying concepts related to emotional intelligence: A proposed glossary, emotional intelligence in everyday life ( $2 \mathrm{nd}$ ed.). New York: Psychological Press.

Meyer, J. P., Allen, N. J. \& Smith, C. (1993). Commitment to Organizations and Occupations: Extension and Test of a Three-component Conceptualization. Journal of Applied Psychology, 78, 538-551. https://doi.org/10.1037/0021-9010.78.4.538

Orhan, N., \& Dincer, H. (2012). The impacts of emotional intelligence competency on job satisfaction in the service sector: An application on the Turkish banking sector. Asian Economic and Financial Review, 2(5), 617-634.

Peng, J., Li, D., Zhang, Z., Tian, Y., Miao, D., Xiao, W., \& Zhang, J. (2016). How can core self-evaluations influence job burnout? The key roles of organizational commitment and job satisfaction. Journal of Health Psychology, 21(1), 50-59. https://doi.org/10.1177/1359105314521478

Sarwar, S., \& Abugre, J. (2013). The influence of rewards and job satisfaction on employees in the service Industry Swansea University, Wales, UK. The Business \& Management Review, 3(2), 22-32.

Shafiq, M., \& Rana, R. A. (2016). Relationship of emotional intelligence to organizational commitment of college teachers in Pakistan. Eurasian Journal of Educational Research, 16(62), 1-14. https://doi.org/10.14689/ejer.2016.62.1

Sinha, A. K., \& Jain, A. K. (2004). Emotional intelligence: Imperative for the organization. Journal of Vocational Behavior, 49, 252-276.

Siron, R. B. T., Muttar, A. K., \& Ahmad, Z. A. (2015). Leader-member exchange and academic job performance in the Iraqi technical colleges and institutes: the mediating role of job satisfaction. International Review of Management and Business Research, 4(3), 671-682.

Siron, R. B., Muttar, A. K., Ahmad, Z. A., \& Tarsipan, M. A. B. (2016). The mediating role of job satisfaction on the relationship between work alienation and job performance. International Business Management, 10(16), 3598-3606.

Sosyal, E., \& Dergisi, B. (2018). Examination of the relationship between job satisfaction levels and organizational commitments of tourism sector employees: A research in the Southeastern Anatolia Region of Turkey. Electronic Journal of Social Sciences, 65(65), 356-366.

\section{Copyrights}

Copyright for this article is retained by the author(s), with first publication rights granted to the journal.

This is an open-access article distributed under the terms and conditions of the Creative Commons Attribution license (http://creativecommons.org/licenses/by/4.0/). 